\title{
RESPIRATORY EPITHELIUM - PLACE OF ENTRY AND / OR DEFENSE AGAINST SARS-CoV-2 VIRUS
}

\section{AUTHORS}

CORRESPONDENT

Snežana Leštarević

Institute of Histology and Embryology

Faculty of Medicine Pristina

Kosovska Mitrovica

snezana.lestarevic@med.pr.ac.rs

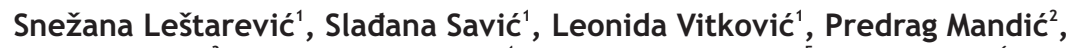

Milica Mijović ${ }^{3}$, Mirjana Dejanović ${ }^{4}$, Dragan Marjanović ${ }^{5}$, Ivan Rančićc ${ }^{6}$, Milan Filipović ${ }^{7}$

${ }^{1}$ Institute of Histology and Embryology, Faculty of Medicine Prishtina - Kosovska Mitrovica

${ }^{2}$ Institute of Anatomy, Faculty of Medicine Prishtina - Kosovska Mitrovica

${ }^{3}$ Institute of Pathological Anatomy, Faculty of Medicine Prishtina - Kosovska Mitrovica

${ }^{4}$ Institute of Physiology, Faculty of Medicine Prishtina - Kosovska Mitrovica

${ }^{5}$ Dental Clinic, Faculty of Medicine Pristina - Kosovska Mitrovica

${ }^{6}$ Institute of Histology and Embryology, Faculty of Medicine, Nis

${ }^{7}$ Clinic of Surgery, Faculty of Medicine Prishtina - Kosovska Mitrovica

\section{SUMMARY}

Coronavirus Disease (COVID-19) is caused by the RNA virus SARS-CoV-2. The primary receptor for the virus is most likely Angiotensin-converting enzyme 2 (ACE2), and the virus enters the body by infecting epithelial cells of the respiratory tract. Through the activation of Toll Like Receptors (TLRs), epithelial cells begin to synthesize various biologically active molecules. The pathophysiology of the COVID 19 is primarily attributed to the hyperactivation of host's immune system due to direct damage to the cells, with consequent release of proinflammatory substances, but also due to the activation of the innate immune response through the activation of alveolar macrophages and dendrite cells (DC). A strong proinflammatory reaction causes damage to alveolar epithelial cells and vascular endothelium. Respiratory epithelial cells, alveolar macrophages and DC are likely to be the most important cells involved in the innate immune response to the virus, since prolonged and excessive SARS-CoV-2-induced activation of these cells leads to the secretion of cytokines and chemokines that massively attract leukocytes and monocytes to the lungs and cause lung damage.

Keywords: SARS-CoV-2 virus, respiratory system, immune response, cytokine storm

\section{SRPSKI}

\section{SAŽETAK}

Korona virusnu bolest (COVID-19) uzrokuje RNK virus SARS-CoV-2. Primarni receptor za virus najverovatnije je angiotenzin konvertujući enzim 2 (ACE2), a virus ulazi u telo inficiranjem epitelnih ćelija respiratornog trakta. Aktivirane preko TLR (eng. Toll Like Receptors) epitelne ćelije počinju da sintetišu različite biološki aktivne molekule. Patofiziologija COVID-19 se pre svega pripisuje "preteranoj aktivaciji imunskog sistema" domaćina usled direktnog oštećenja ćelija i oslobađanja proinflamatornih supstanci i aktiviranja urođenog imunskog odgovora mobilizacijom alveolarnih makrofaga i dendritskih ćelija. Snažna proinflamatorna reakcija izaziva oštećenje alveolarnih epitelnih ćelija i vaskularnog endotela. Verovatno da su ćelije respiratornog epitela, alveolarni makrofagi i dendritske ćelije najznačajnije ćelije uključene u urođeni imunski odgovor na prisustvo virusa, a prolongirana i preterana aktivnost ovih ćelija podstaknuta virusom SARS-CoV-2 dovodi do lučenja citokina i hemokina koji masovno privlače leukocite i monocite u pluća i uzrokuju oštećenja pluća.

Ključne reči: virus SARS-CoV-2, respiratorni trakt, imunski odgovor, citokinska oluja 


\section{INTRODUCTION}

The novel coronavirus (2019-nCoV) is a new strain of the virus, first identified in the human population about a year ago. Until December 2019, 6 types of coronavirus that are pathogenic to humans were known. These are $\mathrm{HCoV}-\mathrm{OC} 43$, HCoV-229E, HCoV-NL63, HCoV-HKU1, SARS-CoV and MERSCoV. At the end of 2019 a pandemic began, caused by the newly discovered type of coronavirus SARS-CoV-2, which is, according to its genetic structure, very similar to the SARS $\mathrm{CoV}$ virus. The disease caused by $\mathrm{nCoV}$ is called COVID-19 (Coronavirus Disease of 2019) [1].

The epidemic potential and pathogenicity of coronaviruses to humans were first demonstrated in 2002, when the SARS-CoV virus (Severe Acute Respiratory Syndrome Coronavirus) caused the SARS epidemic in China, and again in 2012, 2013 and 2015, when MERS-CoV (Middle East Respiratory Syndrome Coronavirus) caused the MERS epidemic in Saudi Arabia and the Republic of Korea [1].

The clinical manifestations of COVID-19, similar to the clinical symptoms that occur in SARS, include: dry cough, sore throat, fever, fatigue, poor general condition, muscle and chest pain, shortness of breath. Symptoms of patients infected with SARS-CoV-2 virus range from minimal to severe respiratory failure followed by multiple organ failure. Severe Acute Respiratory Syndrome (SARS) can be the most serious complication. Chest X-rays of the patients typically show signs of bilateral pneumonia or bilateral, multiple lobular or segmental areas of lung parenchyma consolidation, while computed tomography (CT) scans of the lungs show characteristic bilateral ground-glass opacity (GGO), even in asymptomatic patients.

Symptoms and signs of damage to the small intestine (diarrhea, nausea, vomiting), liver (increased aminotransferases), kidneys (acute renal failure), nervous system (headache, loss of sense of smell and taste, confusion) and heart (acute heart damage with elevated troponin levels) are common. High values of CRP, ferritin, elevated D-dimer, severe leukopenia and lymphopenia, thrombocytopenia and elevated levels of proinflammatory cytokines (interleukins IL-6 and IL-2) may indicate the development of an excessive immune response to the virus and potential death. [2].

\section{SARS-CoV-2 VIRUS}

SARS-CoV-2 virus belongs to $B$ coronaviruses, a large family of RNA viruses. It consists of a lipid envelope and a positively oriented single-stranded ribonucleic acid (ssRNA), with a length of about 30 thousand nucleotide pairs (kb). The virion measures 50 to $200 \mathrm{~nm}$ in diameter and contains surface proteins in the lipid bilayer: S-protein (spike), E-protein (envelope) and M-protein (membrane). The structural protein in the nucleus of the virus is $\mathrm{N}$-protein (nucleocapsid), RNA-containing polymeric protein [2,3,4]. In addition to structural proteins, the viral genome encodes 16 non-structural proteins, including RNA-dependent RNA polymerase (RdRp), replication enzyme of the virus, proteases, proteins that enable folding of the virus, and proteins that interfere with the function of interferon (IFN), the antiviral molecules of our cells [41].

Through the spike $S$ glycoprotein of the envelope, which gives the virus its specific appearance after which it got its name (lat. Corona - crown), the SARS-CoV-2 virus binds to ACE2 receptors (angiotensin converting enzyme 2) on the surface of human cells (Fig. 1).

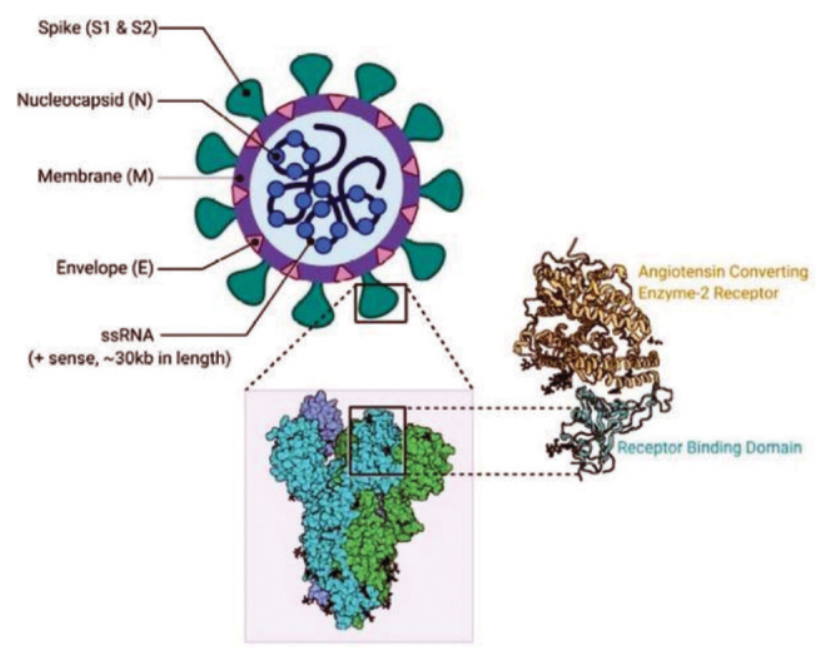

Figure 1. Structure of SARS-CoV-2

(Contributed by Rohan Bir Singh, MD; Made with Biorender.com)

S-glycoprotein is a transmembrane protein with a carboxyl terminus directed towards the cytosol, which consists of two subunits - S1 and S2. The S1 subunit binds the ACE 2 cell receptor via the RBD (receptor-binding domain), which leads to a conformational change of the S2 subunit, enabling the fusion of the cell membrane and the viral envelope [7]. Host's proteolytic enzymes bound to the cell membrane - furin and transmembrane serine protease 2 (TMPRSS2), which perform chemical cleavage of $S$ protein subunits (part known as a furin-clevage site) removing the $\mathrm{S} 1$ domain, enable fusion via the S2 domain and SARS-CoV-2 entry into the cell $[8,9]$.

Corona viruses enter a cell in two ways. The first method is fusion of viral and cell membranes, and the second is clathrin-mediated endocytosis (Fig. 2). In both cases, the entry of SARS-CoV-2 virus into human cells is a complex process involving receptors on the surface of the plasmalemma $[5,6]$. The corona virus uses angiotensinconverting enzyme 2 as a receptor to enter the cell. ACE2 is a type I transmembrane glycoprotein, and its expression is tissue-specific and immunohistochemically confirmed in the endothelial cells of the coronary arteries, arterioles, and myocardial venules [10]. ACE2 has been shown to be expressed in the epithelial cells of the renal tubules [11], predominantly in the apical regions of the plasmalemma [12]. A study examining the expression of ACE2 in human tissues found the highest level of expression in the heart, kidneys, testicles and all parts of the gastrointestinal tract, especially in the ileum. Relatively low levels of ACE2 expression have been found in the central nervous system and lymph tissues [13].

Zou et al. point out that a high density of ACE2 receptors exists in the lungs, heart, esophagus, kidneys, bladder and distal part of the small intestine, which also explains the tendency of the virus to bind to these organs [14]. The expression of angiotensin-converting enzyme 2 is particularly evident on the ciliated cells of the respiratory epithelium, as well as on type 2 pneumocytes in the alveolar epithelium. The presence of this receptor has also been confirmed in oral mucosal cells, especially on the tongue $[15,16]$. ACE2 receptors and transmembrane serine protease 
2 (TMPRSS2) were also found in supporting cells, and to a much lesser extent in olfactory cells of the olfactory epithelium of the olfactory mucosa [17]. The expression of ACE2 receptors on these cells is significantly more pronounced than the expression on the epithelial cells of the respiratory epithelium in its upper segments. This may to some extent explain the olfactory dysfunction associated with SARS-CoV-2 (in about $85 \%$ of cases, patients with Covid19 present with a loss of sense of smell) $[18,19]$.

Compared to SARS-CoV, nCoV has 10-20 times higher affinity for ACE-2, which allows it to easily replicate in the epithelium of the upper respiratory tract, despite the relatively low expression of ACE-2 on cells of that region [ 42 , 43]. The easy entry into the cells probably explains the relatively large number of copies of the virus in the upper respiratory tract [44], the increased level of virus release [45] and significantly easier transmission [46], compared to SARS-CoV. Sungak et al. conclude, based on their research, that the upper respiratory tract is the initial site of SARSCoV-2 virus infection [20].



Figure 2. Entry of SARS-CoV-2 into the cell by endocytosis (A) and fusion (B) [98]

The entry of the corona virus into the host cell results in the degradation of the nucleocapsid and the release of viral RNA into the cytoplasm of the cell. In the second phase of the virus life cycle, the process of replication, transcription, translation, and then the synthesis of viral proteins take place. Viral proteins and newly synthesized viral RNA molecules are transported to the endoplasmic reticulum and the Golgi apparatus, and the newly formed virions are packed in vesicles and released from the cell. The entire replicative cycle of the virus takes place in the cytoplasm of the cell, where the virus causes the death of the infected cell, i.e. it shows a cytotoxic effect [6]. SARS-CoV-2 initially enters and replicates in the epithelial cells of the upper respiratory tract, and virus replication can also be observed in the epithelial cells of the small intestine, while it is significantly less represented in nerve cells [21, 22]. In the lower parts of the respiratory tract, SARS-CoV-2 infects type 2 alveolar epithelial cells, leading to their death by apoptosis and pyroptosis $[47,48]$.

\section{RESPIRATORY AND IMMUNE SYSTEM RESPONSE TO SARS-CoV-2}

The response of the immune system is crucial for the control and protection of the organism from corona virus infection, and research has shown that the body's immune response to SARS-CoV-2 includes both nonspecific (innate) and specific (acquired) immunity. The goals of the innate and acquired immune response to viruses are to limit infection and remove infected cells [23] and for this purpose viral respiratory infections induce an early nonspecific response of epithelial, endothelial, phagocytic and mononuclear cells, as well as a specific T-cell immune response [24].

Innate immunity is the body's first line of defense. In this defense, the respiratory epithelium acts together with innate immune cells (monocytes / macrophages, neutrophils, NK cells (Natural Killer Cells)). Due to the narrow intercellular spaces and strength of intercellular connections, mucociliary transport (respiratory mucus and ciliary cells) as well as the production of antimicrobial substances (nitrogen monoxide - NO, enzymes, protease inhibitors and antimicrobial peptides B-defensin and cathelicidin), the respiratory epithelium represents a significant barrier to virus entry [100]. Namely, antiviral mechanisms of antimicrobial substances include action on almost all phases of the virus life cycle: binding of the virus to the cell, fusion of the virus with the cell membrane, entry of the virus into the cell, multiplication of the viral nucleic acid and synthesis of viral proteins. Airway epithelial cells secrete beta-defensins, but antimicrobial substances are also found in alveolar macrophages, as well as lymphocytes in the lamina propria of the large airways and in the alveoli $[49,50]$.

The main mechanisms of innate immunity against the virus involves the action of interferon type I and NK cells [23]. Natural killer cells (NK cells), with the morphology of large granular lymphocytes and the ability to cause lysis of the target cells without prior sensitization and restriction from MHC molecules (Major Histocompatibility Complex), make up $10-15 \%$ of the peripheral blood lymphocyte population. NK cells selectively cause lysis of the virusinfected target cells, thereby interfering with viral dissemination during the early stages of infection. They may do so through a direct cytotoxic effect, antibody-dependent cytotoxicity and cytokine secretion: interferon gamma (IFNY), tumor necrosis factor a (TNF-a) and Granulocytemacrophage colony-stimulating factor (GM-CSF) [51]. Surface receptors of NK cells enable the recognition of target cells, which is a basic step in the process of cytotoxicity [5255]. Toll-like receptors belong to pattern recognition receptors (PRRs) and recognize pathogen-associated molecular patterns (PAMP) derived from microorganisms and molecular patterns of damage (DAMP-damage-associated molecular patterns), that originate from damaged tissue. PAMP and DAMP trigger signaling pathways that lead to the activation of transcription factors: nuclear factor kappa B $\mathrm{NF}-\mathrm{KB}$, activation protein $\mathrm{AP}-1$ and interferon regulation factor 3 (IRF3) and consequent transcription of genes dependent on them, such as genes for proinflammatory cytokines interleukin-1 (IL-1), interleukin-6 (IL-6), interleukin-8 (IL-8), TNF - $\alpha$ and interferon. TLR receptors initiate a primary immune response that provides immediate protection against various pathogens and induce the acquired immune system through induction of dendritic cell mobilization and maturation [56, 57]. Induction of dendritic cell maturation by TLR represents an important functional link between innate and acquired immune response, which allows efficient interaction of dendritic and T-cells. Also, NK cells contribute to the effector status of monocytes and dendritic cells through direct or indirect mechanisms [57]. 
SARS-CoV-2 inhibits the production of interferon (IFN) type I, II and III more efficiently than SARS-CoV and MERS$\mathrm{CoV}[58,59]$, which further explains the high levels of the virus in the upper respiratory tract, as well as the high rate of transmission in the pre-symptomatic stage and by asymptomatic people [60]. Given the partial matching of the genome sequence, it is assumed that SARS-CoV-2 modulates host immune responses in a similar manner as the other mentioned types of coronavirus [25].

On the other hand, the death of alveolar and endothelial cells due to viral infection leads to the release of molecular patterns of damage (DAMP) [61-63]. DAMPs released by dead cells are ligands for the receptors of the innate immune cell, such as macrophages. Alveolar macrophages are large, wandering cells that reside in pulmonary alveoli and the inter-alveolar septum in close proximity with pneumocytes. They have a high phagocytic and microbicidal potential and represent the first line of defense against inhaled substances. In addition to acting as phagocytes, they also participate in the presentation of antigens to immunocompetent lymphocytes [40]. Alveolar macrophages can recognize antigens (Ag) via TLR [100]. Macrophages possess numerous membrane receptors, with Fc receptors, complement receptors and lectin receptors being the most important for phagocytosis. Receptors for macrophage-activating cytokines such as interleukin 1 (IL-1) and tumor necrosis factor (TNF), IFN- $\gamma$, interleukins IL-2, IL4, IL-10, growth factors CSF-1 (colony stimulating factor), GM-CSF and transforming growth factor beta (TGF-B) are also important. In addition to receptors, surface markers on macrophages, such as the transferrin receptor CD71, a membrane glycoprotein of the integrin- $B$ family, also play an important role. Morphologically, alveolar macrophages are large, mature cells, similar to tissue macrophages [40].

Activated alveolar macrophages play a major role in maintaining immune homeostasis in the lungs, following pathogen invasion and tissue damage due to inflammation. The main mechanisms include phagocytosis of dying cells, secretion of anti-inflammatory mediators - TGF- $B$, prostaglandin E2 (PGE2) and polyenoic fatty acids, and inhibition of T-cell activation in the circulation $[64,65]$. Following activation by coronaviral infection, macrophages secrete a significant amount of proinflammatory cytokines and chemokines such as interleukins IL-1, IL-6, IL-8, IL-10, tumor necrosis factor- $\alpha$ (TNF- $\alpha$ ), and synthesize platelet activating factor (PAF), prostaglandin E2, thromboxane B2 (TxB2), as well as reactive oxygen species (ROS) [25-27]. TNF and IL-1 induce endothelial cell activation $[66,67]$, leading to a significant increase in pulmonary vascular endothelial permeability [68]. Endothelial cell activation also stimulates the recruitment of circulating neutrophils through the regulation of surface membrane chemokines, most notably CCL5 and CXCL1, monocyte chemotactic protein-1 (MCP-1) and IL-8, the surface adhesion protein P-selectin, Vascular Cell Adhesion Molecule -1 (VCAM-1), Intracellular Adhesion Molecule-1 (ICAM-1), as well as a number of glycosaminoglycans, which play an important role in neutrophil binding and migration [72]. Although they play an important role in nonspecific defense mechanisms against the virus, strong recruitment of alveolar macrophages in the lungs and production of large amounts of proinflammatory cytokines can also elicit an enhanced immune response. In viral infection, they support the function of dendritic cells [28].

Other resident immune cells can be found in the respiratory epithelium: dendritic cells, cytotoxic CD8 + T lymphocytes, as well as other types of $T$ lymphocytes (Invariant Natural Killer T Cells; iNKT cells, gamma-delta T cells; $ү \delta \mathrm{T}$ cells) which together with innate immune cells participate in the defense against the virus. The respiratory epithelium represents the link between innate and acquired immunity to viral infection through the production of cytokines and chemokines that lead to the attraction, differentiation, maturation and activation of $T$ and $B$ lymphocytes [100].

Dendritic cells (DC) play a key role in "linking" innate and acquired immunity after viral infection. Functionally, they are antigen-presenting cells and are probably primarily responsible for the presentation of the coronavirus antigen and the consequent induction of the cellular response. After endocytosis and proteolytic degradation of antigen (Ag), DC drain into local lymph nodes and presents Ag through the MHC class II molecules to naive helper T-lymphocytes (CD4 + T-lymphocytes; Th) thus mediating the development of Th1 response, which is crucial in defense against the virus (Fig. 3 ). The development of the Th1 immune response is also stimulated by IL-12, IL-18, IFN- $\alpha$ and IFN- $B$. These cytokines are released by activated macrophages and DC after activation by intracellular pathogens [97]. Type I interferons (IFN- $\alpha$ and $B$ ) also promote the Th1 response [70]. IFN- $\alpha$ leads to up-regulation of the $B$-chain of the IL-12 receptor [71]. INF type II (INF- $\gamma$ ) further initiates differentiation towards the Th1 response. Th1 cells, for its part, secrete the cytokines TNF- $\alpha$ and IL-2. Cytotoxic CD8 + T-lymphocytes recognize the viral antigen of the infected cell within the MHC class I molecules, which is present on most cells, leading to (1) the release of the antiviral cytokines TNF- $a$ and INF type I (INF-a), (2) release of cytotoxic granules with proteases leading to the apoptosis of the virus-infected cell and (3) activation of the caspase cascade and death of the target cell via Fas/FasL interaction of signaling molecules on the surface of activated CD8 + T-lymphocytes [29, 30, 100].

In homeostatic conditions, the presentation of antigen by immature DC leads to the establishment of antigen tolerance, which includes the expression of inhibitory molecules PD-L1 (Programmed death-ligand 1), ILT3 (Immunoglobulin like transcript 3), ILT4 (Immunoglobulin like transcript 4) on DC and induction of regulatory $T$ lymphocyte activity (Treg). On the other hand, activation of DC, through PAMP and proinflammatory cytokines, leads to maturation of DC, which is reflected in the expression of costimulatory molecules and the presentation of antigens in the immunogenic form. Dendritic cells also produce TNF-a, which facilitates phagocytosis by macrophages, and are an important link in activating NK cells [33]. NK cells can also directly (without the mediation of DC) kill a cell infected with the virus. Also, NK lymphocytes produce TNF- $a$ and interferon type II (INF- $\gamma$ ) which have a feedback effect on DC and macrophages and enhance the immune response. Cytokines that produce DC have the most important role in the regulation of Th lymphocyte differentiation into different subpopulations - Th1, Th17, Th2 or Treg.

The resulting effector $T$ cells further regulate the cellular and humoral immune response.

Th1 cells play a role in macrophage activation, production of opsonizing and complement-binding antibodies, cellular cytotoxicity reactions, and initiation of cellular immune responses, which are all important for defense against intracellular infectious agents [69].

The cytokine secretion profile of Th17 cells is very pleomorphic. The basic cytokine is IL-17, which acts through 
its own IL-17 receptors, which are ubiquitously distributed, since they are located on the surface of fibroblasts, B and T lymphocytes, mononuclear cells and vascular endothelial cells [31]. Stimulation of the IL-17 receptor activates the transcription factor NF-KB and the MAPK (Mitogen-Activated Protein Kinase) signaling pathway, which induce the production of different types of chemokines (CCL2, CCL7, CCL20 and CXCL1), i.e. signaling molecules with chemotactic effect, interleukins (IL-6, IL-8), as well as matrix metalloproteinases 3 and 13 (MMP3, MMP13). In summary, all the mediators produced by the action of $\mathrm{IL}-17$ induce neutrophil infiltration and inflammation, making IL-17 a very potent proinflammatory cytokine [32].

Treg cells play an important role in the prevention and resolution of acute respiratory distress syndrome (ARDS). Namely, they inhibit the effects of IL- 6 and stimulate the differentiation of alveolar macrophages to an antiinflammatory M2 phenotype, which predominates in physiological conditions [74]. Treg also alleviate uncontrolled inflammation through the secretion of antiinflammatory cytokines IL-10 and TGF- $B$, which reduce the production of TNF and IL-1B by resident and infiltrating macrophages [73, 74].

Acquired immunity to viral infections includes the action of antibodies that block the binding and entry of the virus into the host cell, as well as cytotoxic T lymphocytes that kill infected cells. In addition to killing infected cells, cytotoxic T lymphocytes activate nucleases that degrade the viral genome, and secrete interleukins, chemokines, transforming growth factor (TGF), and hematopoietic colony stimulating factors (CSF) [28].

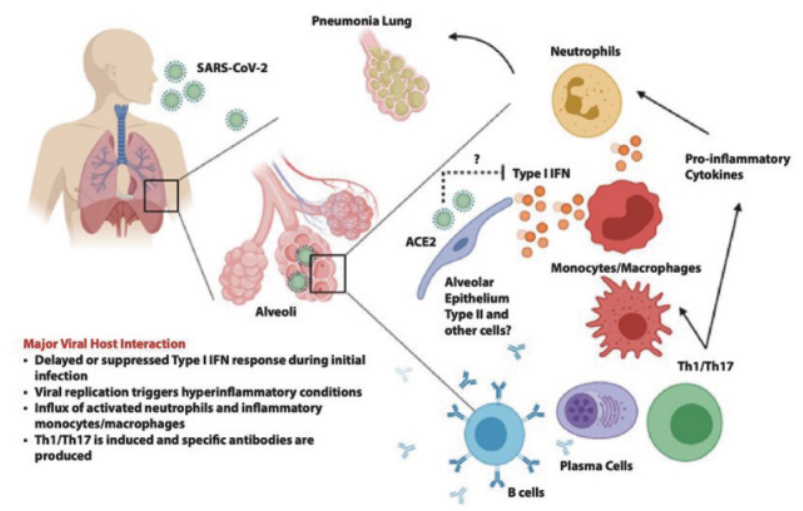

Figure 3. Presumed immune response to SARS-CoV-2 virus [101]

When the virus crosses the first barrier (mucociliary transport and antiviral factors such as defensin and cathelicidin), it reaches the epithelial cells. Intracellular viral RNA is recognized by TLR, leading to activation of nuclear factor kappa $B(N F-k B)$ and transcription of genes of IL-18 and IL-1B pro-forms (pro-IL-1B, pro-IL-18), procaspase 1 and pro-INF I as well as pro-INF III [100]. Activation of the NLRP3 receptor (NOD-like receptor pyrin 3 ) is another signal for the activation of the inflammasome, which is responsible for caspase-mediated cleavage of pro-forms into active IL1B, IL-18, INF I and INF III. Inflammasomes are multimeric complexes formed in cells in response to various physiological and pathological stimuli. They are one of the basic mechanisms of innate immunity and are needed to remove pathogens or damaged cells. They consist of the receptor and caspase-1. NLRP3 receptor might be the most thoroughly studied. Toll-like Receptors are located inside and on the surface of epithelial cells, which makes them able to recognize viral RNA not only within the cell, but also on the outside. The key consequence of receptor activation by the virus is interferon production. IFN type I (IFNa and IFNB) and type III (INFO) rapidly induce antiviral activity by stimulating the expression of hundreds of genes, grouped as IFN-stimulated genes (ISGs). These genes suppress the transcription of viral genes, thus limiting the replication and spread of the virus and further aiding the immune response in neighboring cells $[30,100]$. Nuclear factor-kB leads to increased gene expression for proinflammatory cytokines (IL-1, IL-2, IL-6, IL-11, GM-CSF, TNF- $\alpha$ ), inflammatory enzymes (inducible form of nitric oxide synthetase - iNOS, inducible form of cyclooxygenase - COX 2, 5-lipoxygenase and phospholipase A2 (PLA2)), adhesive molecules (ICAM-1, VCAM-1 and E selectin) and receptors for IL-2 - IL2R (i3 chain of $T$ cell receptor). The action of secretory products of these genes results in a prolongation of the inflammatory process $[34,28]$. By acting on epithelial cells, TNF-a stimulates the secretion of IL-6, IL-8 and GM-CSF, as well as the expression of adhesive molecules ICAM-1 and VCAM-1 on the surface of epithelial and endothelial cells, resulting in an increased migration of inflammatory cells into the airways. IL-6 is a potent stimulator of $\mathrm{T}$ cell activation and proliferation [35, 28]. The respiratory epithelium also produces GM-CSF, which acts via JAK-2 / STAT 5 (JAK - Janus kinase, STAT - signal transducer and activator of transcription) signaling, stimulating myeloid hematopoietic cells (including macrophages and DC) proliferation, differentiation, survival and function $[29,30,100]$.

High levels of proinflammatory cytokines and reactive oxygen species secreted by alveolar macrophages and activated epithelial cells activate platelets in the pulmonary circulation [75]. Activated platelets themselves become a significant source of proinflammatory cytokines and reactive oxygen species [76-78]. Neutrophils and platelets form complexes that move more slowly through the circulation, which in combination with increased endothelial adhesion leads to increased sequestration of neutrophils and platelets in small blood vessels of the lungs [79-81]. Activated platelets and neutrophils mutually enhance the production of proinflammatory cytokines and reactive oxygen species [82-86]. This facilitates the activation of neutrophils, enhancing their capacity for phagocytosis and the release of ROS, as well as other cytotoxic molecules such as myeloperoxidase [87-88]. Platelets also stimulate the release of neutrophilic extracellular traps (NETs) [89-90], DNA fibers of neutrophils that play a role in phagocytosis, leading to the death of pathogens [91-93]. In turn, NETs stimulate platelet activation, aggregation, and tissue factormediated thrombin activation, resulting in enhanced intravascular coagulation [94-96].

\section{CYTOKINE STORM}

Prolonged and excessive activity of respiratory epithelial cells, residential macrophages and DC, stimulated by the SARS-CoV-2 virus, leads to the secretion of cytokines and chemokines that massively attract leukocytes and monocytes into the lungs and cause lung damage. The main cytokines of the innate immune response are: TNF- $\alpha$, IL-1, IL-2, IL-6, IL-8, IL-12, IL-18, INF- $\gamma$, GM-CSF. Thereafter, with the presentation of the antigen, through the action of cytokines, T-lymphocytes are activated. All of the above 
leads to the emergence of so-called cytokine storm (Fig. 4). The severe clinical picture of COVID-19, in which acute respiratory distress syndrome (ARDS) develops, is thought to be caused by a cytokine storm, suggesting that the fatal outcome is caused by an excessive inflammatory response triggered by the virus. Elevated levels of cytokines and chemokines are recorded in the serum of patients with ARDS: IL-1ß, IL-7, IL-8, IL-9, IL-10, IL-17, G-CSF (Granulocyte Colony-Stimulating Factor), GM-CSF, IFNa, TNF-a, IP10 (Inducible Protein 10), MCP1 (Monocyte Chemoattractant Protein 1), MIP1a (Macrophage Inflammatory Protein 1-a) and VEGF [36]. Chemokines (IL-18, IP10, MCP1, MIP1a) attract immune cells (polymorphonuclear leukocytes, macrophages, T-lymphocytes) and increase the inflammatory infiltrate. G-CSF is responsible for granulocytopoiesis and the recruitment of neutrophils and macrophages. IL-1 1 , IL- 6 and TNF- $\alpha$ cause inflammation and general symptoms, such as fever. The Th1 and Th17 responses are thought to be important in the cytokine storm, and TNF-a, IL-6, IL-17A, G-CSF, and GM-CSF are responsible for the excessive inflammatory response [37, 100]. The cytokines IL-6, TNF- $a$, IL-17 and GM-CSF are part of the Th17 response. There are currently no data that other cytokines (IL-21, IL-22, IL-23 and TGF- $\beta$ ) of Th17 response are elevated in COVID-19 [38, 39].

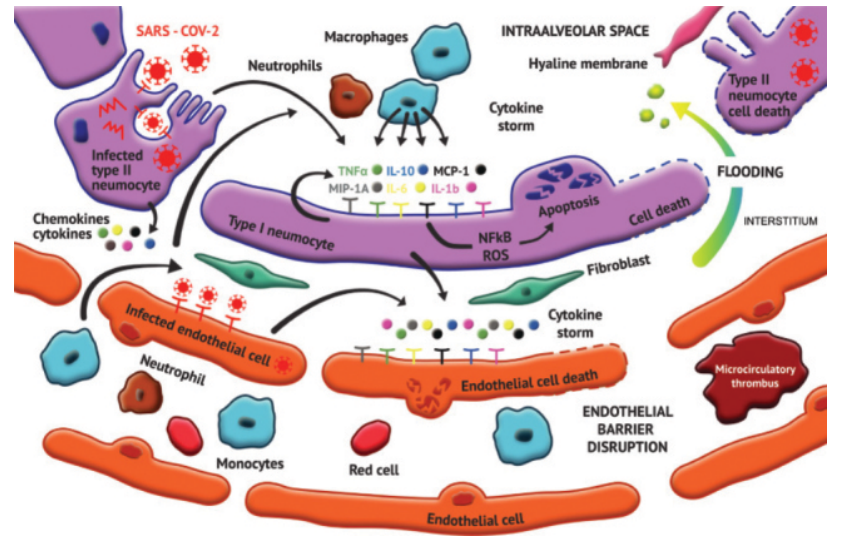

Figure 4. Pathophysiological mechanism of lung damage caused by SARS-COV-2 virus [99]

\section{CONCLUSION}

Coronavirus disease (COVID-19) is a new pandemic disease caused by the RNA virus of severe acute respiratory syndrome (SARS-CoV-2). The primary receptor for the virus in humans is most likely angiotensin converting enzyme 2 (ACE2). The pathophysiology of severe COVID-19 is attributed to hyperactivation of the host immune response due to direct damage to the cells and release of proinflammatory substances, as well as activation of the innate response by mobilization of alveolar macrophages and dendritic cells. A strong proinflammatory reaction causes damage to alveolar epithelial cells and vascular endothelium, as well as microvascular microthromboses, which lead to the development of ARDS. It may be proposed that respiratory epithelial cells, alveolar macrophages and DC are the most important cells involved in the innate immune response to the virus, and prolonged and excessive activity of these cells stimulated by SARS-CoV-2 virus leads to the secretion of cytokines and chemokines that attract leukocytes and monocytes to the lungs and cause lung damage. The major cytokines of the innate immune response include TNF- $\alpha$, IL-1, IL-2, IL-6, IL-8, IL-12, IL-18, INF- $\gamma$ and GM-CSF. Many unanswered questions about the biological, epidemiological, and clinical characteristics of COVID 19 make it virtually impossible to predict the further course of the current pandemic.

\section{REFERENCES}

1. World Health Organisation (WHO). Middle East respiratory syndrome coronavirus (MERS-CoV). World Health Organization. 2019; Dostupno na: https://www.who.int/emergencies/mers-cov/en/.

2. Wei G, Zheng N, Yu H, Wen L, Chun O, Jian H, et al. Clinical Characteristics of Coronavirus Disease 2019 in China. New England Journal of Medicine. 2020; 382: 1708 - 1720.

3. Wu C, Liu Y, Yang Y, Zhang P, Zhong W, Wang Y, et al. Analysis of therapeutic tar-gets for SARS-CoV-2 and discovery of potential drugsby computational methods. Acta Pharm Sin B. 2020; 10(5):766-788. doi: 10.1016/j.apsb.2020.02.008.

4. Mandelbaum RF. Scientists Create Atomic-Level Image of the New Coronavirus's Potential Achilles Heel. Gizmodo. Archived from the original on 8 March 2020.

5. Zhou P, Yang XL, Wang XG, Hu B, Zhang L, Zhang W, et al. A pneumonia outbreak associated with a new coronavirus of probable bat origin. Nature. 2020; 579: 270 - 273.

6. Lai MM, Cavanagh D. The molecular biology of coronaviruses. Advances in virus research. 1997; 48: 1 - 100.

7. He Y, Zhou Y, Liu S, Kou Z, Li W, Farzan M, Jiang S. Receptor-binding domain of SARS-CoV spike protein induces highly potent neutralizing antibodies: implication for developing subunit vaccine. Biochemical and biophysical research communications. 2004; 324:773-781.

8. Hoffmann M, Kleine-Weber H, Schroeder S, Krüger N, Herrler T, Erichsen S, et al. SARS-CoV-2 Cell Entry Depends on ACE2 and TMPRSS2 and Is Blocked by a Clinically Proven Protease Inhibitor. Cell. 2020; 181: 271 - 280. 
9. Shirato K, Kawase M, Matsuyama S. Middle East respiratory syndrome coronavirus infection mediated by the transmembrane serine protease TMPRSS2. Journal of virology. 2013; 87: 12552 - 12561.

10. Tipnis SR, Hooper NM, Hyde R, Karran E, Christie G, Turner AJ. A human homolog of angiotensin-converting enzyme. Cloning and functional expression as a captopril-insensitive carboxypeptidase. J Biol Chem. 2000; 275, 33238-43.

11. Donoghue M, Hsieh F, Baronas E, Godbout K, Gosselin M, Stagliano N, et al. A novel angiotensin-converting enzyme-related carboxypeptidase (ACE2) converts angiotensin I to angiotensin 1-9. Circ Res. 2000; 87, E1-9.

12. Warner FJ, Lew RA, Smith A, Lambert DW, Hooper NM, Turner AJ. Angiotensin-converting enzyme 2 (ACE2), but not ACE, is preferentially localized to the apical surface of polarized kidney cells. J Biol Chem. 2005; 280, 39353-62.

13. Harmer D, Gilbert M, Borman R, Clark KL. Quantitative mRNA expression profiling of ACE 2, a novel homologue of angiotensinconverting enzyme. FEBS Lett. 2002; 532, 107-10.

14. Zou X, Chen K, Zou J, Han P, Hao J, Han Z. Single-cell RNA-seq data analysis on the receptor ACE2 expression reveals the potential risk of different human organs vulnerable to 2019-nCoV infection. Front Med. 2020 (doi: 10.1007/s11684-020-0754-0).

15. Vaduganathan M, Vardeny O, Michel T, MCMurray JJV, Pfeffer MA, Solomon SD. Renin-angiotensin-aldosterone system inhibitors in patients with covid-19. N Engl J Med. 2020; 382 (17) :1653-9. DOI: 10.1056/NEJMsr2005760

16. Xu H, Zhong L, Deng J, Peng J, Dan H, Zeng X, et al. High expression of ACE2 receptor of 2019-nCoV on the epithelial cells of oral mucosa. Int J Oral Sci. 2020; 24;12(1):8.

17. Bilinska K, Jakubowska P, Von Bartheld CS, \& Butowt R. Expression of the SARS-CoV-2 Entry Proteins, ACE2 and TMPRSS2, in Cells of the Olfactory Epithelium: Identification of Cell Types and Trends with Age. ACS chemical neuroscience. 2020; 11(11), 1555-1562. https://doi.org/10.1021/acschemneuro.0c00210.

18. Bigiani A. Gustatory dysfunctions in COVID-19 patients: possible involvement of taste renin-angiotensin system (RAS). Eur Arch Otorhinolaryngol. 2020; 277(8):2395. DOI: 10.1007/s00405-020-06154-w

19. Chen M, Shen W, Rowan NR, Kulaga H, Hillel A, Ramanathan M, et al. Elevated ACE-2 expression in the olfactory neuroepithelium: implications for anosmia and upper respiratory SARS-CoV-2 entry and replication. Eur Respir J. 2020; 56 (3): 2001948. doi:10.1183/13993003.01948-2020.

20. Sungnak W, Huang N, Bécavin C. Berg M, Queen R, Litvinukova M, et al. SARS-CoV-2 entry factors are highly expressed in nasal epithelial cells together with innate immune genes. Nat Med. 2020;26, 681-687 https://doi.org/10.1038/s41591-020-0868-6.

21. Chu H, Chan JF, Wang Y, Yuen TT, Chai Y, Hou Y, et al. Comparative replication and immune activation profiles of SARS-CoV-2 and SARS-CoV in human lungs: an ex vivo study with implications for the pathogenesis of COVID-19. Clin Infect Dis. 2020;ciaa410. DOI: $10.1093 / \mathrm{cid} / \mathrm{ciaa} 410$

22. Hamming I, Timens W, Bulthuis ML, Lely AT, Navis G, van Goor H. Tissue distribution of ACE2 protein, the functional receptor for SARS coronavirus. A first step in understanding SARS pathogenesis. J Pathol. 2004; 203:631-7. DOI: 10.1002/path.1570.

23. Catanzaro M, Fagiani F, Racchi M, Corsini E, Govoni S, Lanni C. Immune response in COVID-19: addressing a pharmacological challenge by targeting pathways triggered by SARS-CoV-2. Signal transduction and targeted therapy. 2020; 5: 1 - 10.

24. Folkerts G, Busse WW, Nijkamp FP, Sorkness R, Gern JE. Virus induced airway hyperresponsiveness and asthma. Am. J. Respir. Crit. Care Med. 1998; 157, 1708-1720.

25. Prompetchara E, Ketloy C, Palaga T. Immune responses in COVID-19 and potential vaccines: Lessons learned from SARS and MERS epidemic. Asian Pacific journal of allergy and immunology. 2020; 38: 1 - 9.

26. Qin C, Zhou L, Hu Z, Zhang S, Yang S, Tao Y, et al. Dysregulation of immune response in patients with COVID-19 in Wuhan, China. Clinical infectious diseases: an official publication of the Infectious Diseases Society of America. 2020.

27. Matsuzaki Z, Okamoto Y, Sarashina N, Ito E, Togawa K, Saito I. Induction of intracel-lular adhesion molecule-1 in human nasal epithelial cells during respiratory syncytial virus infection. Immunol. 1996; 88: 565-568.

28. Bolevich SB, Litvitsky PF, Grachev SV, Vorobyev SI, Orlova AS, Fokina MA, et al. Fundamental basis of covid-19 pathogenesis. Serbian Journal of Experimental and Clinical Research. 2020; 21(2):93-111.

29. Denney L, Ho LP. The role of respiratory epithelium in host defence against influenza virus infection. Biomed J. 2018; 41:218-33. DOI: $10.1016 / j . b j .2018 .08 .004$.

30. Benam KH, Denney L, Ho LP. How the Respiratory Epithelium Senses and Reacts to Influenza Virus. Am J Respir Cell Mol Biol. 2019; 60:259-68. DOI: 10.1165/rcmb.2018-0247TR

31. Lohr J, Knoechel B, Caretto D, Abbas AK. Balance of Th1 and Th17 effector and peripheral regulatory T cells. Microbes Infect. 2009; 11(5):589-93

32. Dong C. TH17 cells in development: an updated view of their molecular identity and genetic programming. Nat Rev Immunol. 2008; 8(5):337-48.

33. Yoshikawa T, Hill T, Li K, Peters CJ, Tseng CT. Severe acute respiratory syndrome (SARS) coronavirus-induced lung epithelial cytokines exacerbate SARS pathogenesis by modulating intrinsic functions of monocytederived macrophages and dendritic cells. J Virol. 2009; 83(7):3039-48.

34. Welliver RC. Immunologic mechanisms of virus induced wheezing and asthma. J. Pediatr.1999; 135, S14-S20.

35. Martin LD, Rochelle LG, Fischer BM, Krunkosky TM, Adler KB. Airway epithelium as an effector of inflammation molecular regulation of secondary mediators. Eur. Respir. J. 1997;10: 2139-2146.

36. Huang C, Wang Y, Li X, Ren L, Zhao J, Hu Y, et al. Clinical features of patients infected with 2019 novel coronavirus in Wuhan, China. Lancet. 2020; 395:497-506. DOI: 10.1016/S0140-6736(20)30183-5

37. Schett G, Sticherling M, Neurath MF. COVID-19: risk for cytokine targeting in chronic inflammatory diseases? Nat Rev Immunol. 2020; 20:271-2. DOI: 10.1038/s41577-020-0312-7. 
38. Misra DP, Agarwal V, Gasparyan AY, Zimba O. Rheumatologists' perspective on coronavirus disease 19 (COVID-19) and potential therapeutic targets. Clin Rheumatol. 2020; 1-8. DOI:10.1007/s10067-020-05073-9.

39. Ye Q, Wang B, Mao J. The pathogenesis and treatment of the 'Cytokine Storm' in COVID-19. J Infect. 2020; S0163-4453(20)30165-1. DOI: $10.1016 / j$.jinf.2020.03.037.

40. Lohmann-Matthes ML, Steinmüller C, Franke-Ullmann G. Pulmonary macrophages. Eur Respir J. 1994; 7: 1678-1689.

41. Ahmadpour D, Ahmadpoor P. How the COVID-19 Overcomes the Battle? An Approach to Virus Structure. Iranian journal of kidney diseases. 2020; 14:167-72.

42. Bertram S, Heurich A, Lavender H, Gierer S, Danisch S, Perin P, et al. Influenza and SARS-coronavirus activating proteases TMPRSS2 and HAT are expressed at multiple sites in human respiratory and gastrointestinal tracts. PloS one. 2012; 7:e35876.

43. Hamming I, Timens W, Bulthuis ML, Lely AT, Navis G, van Goor H. Tissue distribution of ACE2 protein, the functional receptor for SARS coronavirus. A first step in understanding SARS pathogenesis. The Journal of pathology. 2004; 203:631-7.

44. To KK, Tsang OT, Leung WS, Tam AR, Wu TC, Lung DC, et al. Temporal profiles of viral load in posterior oropharyngeal saliva samples and serum antibody responses during infection by SARS-CoV-2: an observational cohort study. The Lancet. Infectious diseases. 2020;20:565-74.

45. Zou L, Ruan F, Huang M, Liang L, Huang H, Hong Z, et al. SARS-CoV-2 Viral Load in Upper Respiratory Specimens of Infected Patients. The New England journal of medicine. 2020;382:1177-9.

46. Liu Y, Gayle AA, Wilder-Smith A, Rocklöv J. The reproductive number of COVID-19 is higher compared to SARS coronavirus. Journal of travel medicine. 2020;27(2). https://doi.org/10.1093/jtm/taaa021

47. Mossel EC, Wang J, Jeffers S, Edeen KE, Wang S, Cosgrove GP, et al. SARS-CoV replicates in primary human alveolar type II cell cultures but not in type I-like cells. Virology. 2008; 372:127-35.

48. Qian Z, Travanty EA, Oko L, Edeen K, Berglund A, Wang J, et al. Innate immune response of human alveolar type II cells infected with severe acute respiratory syndrome-coronavirus. American journal of respiratory cell and molecular biology. 2013; 48:742-8.

49. Shornick LP, Wells AG, Zhang Y, Patel AC, Huang G, Takami K, et al. Airway epithelial versus immune cell Stat1 function for innate defense against respiratory viral infection. J Immunol. 2008;180(5):3319-28.

50. Wah J, WellekA, Frankenberger M, Unterberger P, Welsch U, Bals R. Antimicrobial peptides are present in immune and host defense cells of the human respiratory and gastrointestinal tracts. Cell Tissue Res. 2006;324(3):449-56.

51. Farag SS, Fehlinger TA, Ruggeri L, Velardi A, Caligiuri $M$. Natural killer cell receptors: new biology and insights into the Graft-versus leukemia effect. Blood. 2002;100(6): 1935-47.

52. Robertson MJ. Role of chemokines in the biology of natural killer cells. J Leukoc Bioi. 2002; 71: 173-83.

53. Ferlazzo G, Munz C. NK cell compartments and their activation by dendritic cells. J 1mmunol. 2004; 172: 1333-9. doi: 10.4049/jimmunol.172.3.1333.

54. Alter G, Teigen N, Davis BT, Addo MM, Suscovich 'fl. Waring MT. et al. Sequential deregulation of NK cell subset distribution and function starting in acute HIV-I infection. Blood. 2005;106( I0):3366-9.

55. O'Connor GM, Hart OM, Gardiner CM. Putting the natural killer cell in its place. Immunology. 2005;117: 1-10.

56. Akira S, Takeda K, Kaisho T. Toll-like receptors: critical proteins linking innate and acquired immunity. Nature Immunol. 2001; 2(8):675-80.

57. Sivori S, Falco M, Chiesa MD, Cariomagno S, Vitale M, Moretta L, et al. CpG and double-stranded RNA trigger human NK cells by Tolllike receptors: induction of cytokyne release and cytotoxicity against tumors and dendritic cells. Proc Natl Acad Sci USA. 2004; 101 :IOI16-21.

58. Blanco-Melo D, Nilsson-Payant BE, Liu WC, Uhl S, Hoagland D, Møller R, et al. Imbalanced Host Response to SARS-CoV-2 Drives Development of COVID-19. Cell. 2020;181:1036-45.e9.

59. Sallard E, Lescure FX, Yazdanpanah Y, Mentre F, Peiffer-Smadja N. Type 1 interferons as a potential treatment against COVID-19. Antiviral research. 2020;178:104791.

60. Liu L, Lei X, Xiao X, Yang J, Li J, Ji M, et al. Epidemiological and Clinical Characteristics of Patients With Coronavirus Disease-2019 in Shiyan City, China. Frontiers in cellular and infection microbiology. 2020;10:284.

61. Faust H, Mangalmurti NS. Collateral damage: necroptosis in the development of lung injury. American journal of physiology. Lung cellular and molecular physiology. 2020; 318:L215-125.

62. Sauler M, Bazan IS, Lee PJ. Cell Death in the Lung: The Apoptosis-Necroptosis Axis. Annual review of physiology. 2019;81:375-402.

63. Ueno H, Matsuda T, Hashimoto S, Amaya F, Kitamura Y, Tanaka M, et al. Contributions of high mobility group box protein in experimental and clinical acute lung injury. American journal of respiratory and critical care medicine. 2004;170:1310-6.

64. Fan EKY, Fan J. Regulation of alveolar macrophage death in acute lung inflammation. Respiratory research. 2018; 19:50.

65. Huang X, Xiu H, Zhang S, Zhang G. The Role of Macrophages in the Pathogenesis of ALI/ARDS. Mediators of inflammation. 2018;1264913.

66. Pober JS, Sessa WC. Evolving functions of endothelial cells in inflammation. Nature reviews. Immunology. 2007;7:803-15.

67. Szmitko PE, Wang CH, Weisel RD, de Almeida JR, Anderson TJ, Verma S. New markers of inflammation and endothelial cell activation: Part I. Circulation. 2003;108:1917-23.

68. Sukriti S, Tauseef M, Yazbeck P, Mehta D. Mechanisms regulating endothelial permeability. Pulmonary circulation. 2014; 4:535-51.

69. Romagnani S. T-cell subsets (Th1 versus Th2). Ann Allergy Asthma Immunol. 2000; 85: 9- 2.

70. Rogge L, D'Ambrosio D, Biffi M. The role of Stat4 in species- specific regulation of Th cell development by type I IFNs. J Immunol. 1998;161: 6567-74. 
71. Rogge L, Barberis L, Passini N. Selective expression of an interleukin 12 receptor component by human Thelper 1 cells. J Exp Med. 1997; 185: 825-31.

72. Mitroulis I, Alexaki VI, Kourtzelis I, Ziogas A, Hajishengallis G, Chavakis T. Leukocyte integrins: role in leukocyte recruitment and as therapeutic targets in inflammatory disease. Pharmacology \& therapeutics. 2015; 147:123-35.

73. Wong JJM, Leong JY, Lee JH, Albani S, Yeo JG. Insights into the immuno-pathogenesis of acute respiratory distress syndrome. Annals of translational medicine. 2019;7:504.

74. Lin S, Wu H, Wang C, Xiao Z, Xu F. Regulatory T Cells and Acute Lung Injury: Cytokines, Uncontrolled Inflammation, and Therapeutic Implications. Frontiers in immunology. 2018;9:1545.

75. Stark K. Platelet-neutrophil crosstalk and netosis. HemaSphere. 2019; 3:89-91.

76. El Haouari M. Platelet Oxidative Stress and its Relationship with Cardiovascular Diseases in Type 2 Diabetes Mellitus Patients. Current medicinal chemistry. 2019;26:4145-65.

77. Freedman JE. Oxidative stress and platelets. Arteriosclerosis, thrombosis, and vascular biology. 2008; 28:s11-6.

78. Violi F, Pignatelli P, Basili S. Nutrition, supplements, and vitamins in platelet function and bleeding. Circulation. 2010;121:1033-44.

79. Graham GJ, Handel TM, Proudfoot AEl. Leukocyte Adhesion: Reconceptualizing Chemokine Presentation by Glycosaminoglycans. Trends in immunology. 2019; 40:472-81.

80. Middleton EA, Weyrich AS, Zimmerman GA. Platelets in Pulmonary Immune Responses and Inflammatory Lung Diseases. Physiological reviews. 2016; 96:1211-59.

81. Ortiz-Muñoz G, Mallavia B, Bins A, Headley M, Krummel MF, Looney MR. Aspirin-triggered 15-epi-lipoxin A4 regulates neutrophilplatelet aggregation and attenuates acute lung injury in mice. Blood. 2014; 124:2625-34.

82. Kornerup KN, Salmon GP, Pitchford SC, Liu WL, Page CP. Circulating platelet-neutrophil complexes are important for subsequent neutrophil activation and migration. Journal of applied physiology. 2010; 109:758-67.

83. Duerschmied D, Suidan GL, Demers M, Herr N, Carbo C, Brill A, et al. Platelet serotonin promotes the recruitment of neutrophils to sites of acute inflammation in mice. Blood. 2013;121:1008-15.

84. Maugeri N, Rovere-Querini P, Evangelista V, Godino C, Demetrio M, Baldini M, et al. An intense and short-lasting burst of neutrophil activation differentiates early acute myocardial infarction from systemic inflammatory syndromes. PloS one. 2012; 7:e39484.

85. Ghasemzadeh M, Hosseini E. Intravascular leukocyte migration through platelet thrombi: directing leukocytes to sites of vascular injury. Thrombosis and haemostasis. 2015;113:1224-35.

86. Page C, Pitchford S. Neutrophil and platelet complexes and their relevance to neutrophil recruitment and activation. International immunopharmacology. 2013; 17:1176-84.

87. Assinger A, Buchberger E, Laky M, Esfandeyari A, Brostjan C, Volf I. Periodontopathogens induce soluble P-selectin release by endothelial cells and platelets. Thrombosis research. 2011;127:e20-6.

88. Gros A, Ollivier V, Ho-Tin-Noé B. Platelets in inflammation: regulation of leukocyte activities and vascular repair. Frontiers in immunology. 2014;5:678.

89. Clark SR, Ma AC, Tavener SA, McDonald B, Goodarzi Z, Kelly MM, et al. Platelet TLR4 activates neutrophil extracellular traps to ensnare bacteria in septic blood. Nature medicine. 2007;13:463-9.

90. Katz JN, Kolappa KP, Becker RC. Beyond thrombosis: the versatile platelet in critical illness. Chest. 2011; 139:658-68.

91. Etulain J, Martinod K, Wong SL, Cifuni SM, Schattner M, Wagner DD. P-selectin promotes neutrophil extracellular trap formation in mice. Blood. 2015;126:242-6

92. Carestia A, Kaufman T, Rivadeneyra L, Landoni VI, Pozner RG, Negrotto S, et al. Mediators and molecular pathways involved in the regulation of neutrophil extracellular trap formation mediated by activated platelets. Journal of leukocyte biology. 2016; 99:15362.

93. Maugeri N, Campana L, Gavina M, Covino C, De Metrio M, Panciroli C, et al. Activated platelets present high mobility group box 1 to neutrophils, inducing autophagy and promoting the extrusion of neutrophil extracellular traps. Journal of thrombosis and haemostasis. JTH. 2014; 12:2074-88.

94. Zucoloto AZ, Jenne CN. Platelet-Neutrophil Interplay: Insights Into Neutrophil Extracellular Trap (NET)-Driven Coagulation in Infection. Frontiers in cardiovascular medicine. 2019;6:85

95. Elaskalani O, Abdol Razak NB, Metharom P. Neutrophil extracellular traps induce aggregation of washed human platelets independently of extracellular DNA and histones. Cell communication and signaling: CCS. 2018; 16:24.

96. Fuchs TA, Brill A, Duerschmied D, Schatzberg D, Monestier M, Myers DD, et al. Extracellular DNA traps promote thrombosis. Proceedings of the National Academy of Sciences of the United States of America. 2010;107:15880-5.

97. Farrar JD, Asnagli H, Murphy KM. T helper subset development: roles of instruction, selection, and transcription. J Clin Invest. 2002;109(4):431-435. https://doi.org/10.1172/JCl15093.

98. Xiu S, Dick A, Ju H, Mirzaie S, Abdi F, Cocklin S, et al. Inhibitors of SARS-CoV-2 Entry: Current and Future Opportunities. Journal of medicinal chemistry. 2020

99. Domingoa P, Mur I, Pomar V, Corominas H, Casademont J, Benito N. The four horsemen of a viral Apocalypse: The pathogenesis of SARS-CoV-2 infection (COVID-19). E Bio Medicine. 2020; DOI:https://doi.org/10.1016/j.ebiom.2020.102887

100. Laktašić Žerjavić N. COVID-19 i vitamin D - postoji li poveznica? Medicus. 2020; 29 (2):219-224.

101. Prompetchara E, Ketloy C, Palaga T. Immune responses in COVID-19 and potential vaccines: Lessons learned from SARS and MERS epidemic. Asian Pac J Allergy Immunol. 2020;38(1):1-9. doi: 10.12932/AP-200220-0772. PMID: 32105090. 